\title{
Direct-to-Consumer Advertising: Public Perceptions of Its Effects on Health Behaviors, Health Care, and the Doctor-Patient Relationship
}

\author{
Elizabeth Murray, PhD, MRCGP, Bernard Lo, MD, Lance Pollack, PhD, \\ Karen Donelan, ScD, and Ken Lee
}

Purpose: To determine public perceptions of the effect of direct-to-consumer advertising (DTCA) of prescription medications on health behaviors, health care utilization, the doctor-patient relationship, and the association between socioeconomic status and these effects.

Methods: Cross-sectional survey of randomly selected, nationally representative sample of the US public using computer-assisted telephone interviewing. Main outcome measures: numbers and proportions of respondents in the past 12 months who, as a result of DTCA, requested preventive care or scheduled a physician visit; were diagnosed with condition mentioned in advertisement; disclosed health concerns to a doctor; felt enhanced confidence or sense of control; perceived an effect on the doctor-patient relationship; requested a test, medication change, or specialist referral; or manifested serious dissatisfaction after a visit to a doctor.

Results: As a result of DTCA, $14 \%$ of respondents disclosed health concerns to a physician, $6 \%$ requested preventive care, $5 \%$ felt more in control during a physician visit; $5 \%$ made requests for a test, medication change, or specialist referral, and $3 \%$ received the requested intervention. One percent of patients reported negative outcomes, including worsened treatment, serious dissatisfaction with the visit, or that the physician acted challenged. Effects of DTCA were greater for respondents with low socioeconomic status.

Conclusions: DTCA has positive and negative effects on health behaviors, health service utilization, and the doctor-patient relationship that are greatest on people of low socioeconomic status. The benefits of DTCA in terms of encouraging hard-to-reach sections of the population to seek preventive care must be balanced against increased health care costs caused by clinically inappropriate requests generated by DTCA. (J Am Board Fam Pract 2004;17:6-18.)

Direct-to-consumer advertising (DTCA) of prescription medications may have beneficial or harmful effects on patients, their relationship with physicians, and the health care system. ${ }^{1-9}$ So far, there are few empirical data on the actual effects of DTCA, and available data are limited by small

Submitted, revised, 24 March 2003.

From the Department of Primary Care and Population Sciences, Royal Free and University College School of Medicine at University College London, United Kingdom (EM), Department of Medicine and Program in Medical Ethics (BL) and Health Survey Research Unit, Center for AIDS Prevention Studies (LP, KL), University of California, San Francisco, and Department of Health Policy and Management, Harvard School of Public Health, Boston, Massachusetts (KD). Address correspondence to Elizabeth Murray, PhD, MRCGP, Department of Primary Care and Population Sciences, Royal Free and University College School of Medicine at University College London, Archway Campus, Holborn Union Building, Highgate Hill, London N19 5LW, United Kingdom (e-mail: elizabeth.murray@pcps.ucl.ac.uk).

This project was funded by the Robert Wood Johnson Foundation. EM was a Harkness Fellow in Health Care Policy 2001-02, supported by the Commonwealth Fund, based in the Program for Medical Ethics at UCSF. samples, ${ }^{10}$ selected populations, ${ }^{11}$ hypothetical scenarios, ${ }^{12}$ or have been criticized on methodological grounds. ${ }^{13,14}$

In an article published in the last issue of the Fournal of the American Board of Family Practice, we examined the effects of DTCA on quality of care, health service utilization, and physician perceptions of its impact on the doctor-patient relationship. ${ }^{15}$ In this article, we use the data from a large telephone survey of a nationally representative sample of the American public to test hypotheses concerning the effects of DTCA on health behaviors, patients' perceptions of its impact on the doctorpatient relationship and on the health care system, and the extent to which these effects are mediated by socioeconomic status.

\section{Methods \\ Development of Testable Hypotheses}

We undertook a literature review to identify published claims about the effects of DTCA and formulate testable hypotheses. ${ }^{15}$ 


\section{Sample}

The survey was conducted between March 2000 and March 2001 on a household probability sample from the 48 contiguous states by using randomdigit dialing to select households and a random selection method to select one respondent aged 18 or over for interview in each sample household. Verbal informed consent was obtained from all respondents before they began the interview. Eligibility was limited to English and Spanish speakers without cognitive or physical impairments that prevented completion of the interview. A small financial incentive was offered for completion of the interview. At least 15 attempts were made to call nonresponders, and where telephone numbers of nonrespondents could be matched with an address, up to 2 letters were sent to encourage response. The average administration time was 20 minutes. All interviews were conducted by trained interviewers using computer-assisted telephone interviewing (CATI).

An oversample of persons in poor health was achieved by screening a random subsample of households and including only those respondents who described their health as fair or poor (rather than excellent, very good, or good); had a disability or handicap that prevented them from participating fully in school, work, housework, or other activities; or had been hospitalized within the past 12 months, for reasons other than a normal delivery of a child. A total of 2720 interviews were completed in the nonoversample portion of the study, representing a completion rate of $72 \%$ and a response rate of $54 \%$, and 489 interviews were completed in the oversample (completion rate, $95 \%$; response rate, $51 \%)$.

Data were weighted to adjust for unequal probability of selection (including the oversample of persons in poor health). To adjust for survey nonresponse, stratification weights were developed using the March 2000 Current Population Survey from the US Census Bureau as standard. The poststratification weights were based on gender within age within race, as well as education, health insurance status (insured versus uninsured), and household size.

\section{Interview and Data Collection}

The interview was developed after literature review and focus group participation and piloted to ensure all questions were easily understood and contained no ambiguities. In the preamble, it was described as a survey on health issues, in particular how Americans make decisions about health care and their feelings about the health care available to them. No mention of DTCA was made in characterizing the survey. Initial questions inquired into respondents' use of different sources of health information, approaches to health information, and relationships with their physicians. Respondents were then asked about their experience of searching the Internet for health information, because this was the primary focus of the project. Once questions about the Internet were completed, respondents were asked for their experiences of DTCA, whether they had encountered an advertisement that was personally relevant, and their response to that advertisement. Respondents who had sequentially seen an advertisement for a prescription medication in the past 12 months, perceived it as personally relevant, and discussed the information in this advertisement with their physician were asked about the last time they had done this. To avoid overloading respondents, those who had already answered questions about taking health information from the Internet to a visit with their doctor $(n=82)$ were not asked about the last occasion on which they had discussed information in an advertisement with their doctor.

Demographic and socioeconomic data, including age, self-defined ethnic origin, educational achievement, household income per annum, health insurance status, and current health status were collected from all respondents. Respondents were defined as being proactive about health care information if they stated that they went out of their way to look for information on health topics of personal relevance, rather than simply reading it if they came across it or not reading any such information.

\section{Analysis}

Dependent variables organized by hypothesis are summarized in Table 1. These variables include the kinds of requests made to physicians based on DTCA, the responses received to such requests, characteristics of the doctor-patient exchange over such requests, and the outcomes from the exchange. In addition, we included the doctor's acting challenged as an important outcome variable, because it had been established as such in our previous work. ${ }^{16} \mathrm{We}$ postulated that the doctor's acting challenged could indicate either that the doctor felt challenged by interacting with an activated, 
Table 1. Summary of Hypotheses Tested, Dependent Variables Used to Test Each Hypothesis, Total Number of Respondents Experiencing Each Outcome, and Association with Socioeconomic Status

\begin{tabular}{|c|c|c|c|}
\hline $\begin{array}{l}\text { Hypothesis*: That DTCA would } \\
\text { result in: }\end{array}$ & DV & $\begin{array}{c}\mathrm{N} \text { (\% of Total } \\
\text { Population) } \dagger[95 \% \mathrm{CI}]\end{array}$ & $\begin{array}{l}\text { Significant Associations } \\
\text { (see text for details) }\end{array}$ \\
\hline \multicolumn{4}{|l|}{ Clinical benefits and harms } \\
\hline $\begin{array}{l}\text { More patients attending } \\
\text { physicians for preventive } \\
\text { health care. }\end{array}$ & $\begin{array}{l}\text { Respondent requested preventive } \\
\text { care from a health professional } \\
\text { Respondent attended physician or } \\
\text { other health professional for a } \\
\text { check-up }\end{array}$ & $\begin{array}{l}203(6.3 \%)[5.3-7.5 \%] \\
189(5.9 \%)[5.0-6.9 \%)\end{array}$ & $\begin{array}{l}\text { Low education, Hispanic, chronic } \\
\text { disease } \\
\text { Low education, Hispanic, chronic } \\
\text { disease }\end{array}$ \\
\hline $\begin{array}{l}\text { Increased diagnoses of currently } \\
\text { under-diagnosed conditions. }\end{array}$ & $\begin{array}{l}\text { Respondent diagnosed with, or } \\
\text { told at risk of, condition } \\
\text { mentioned in advertisement } \\
\text { during or after consultation }\end{array}$ & $28(0.9)[0.6-1.3 \%]$ & $\begin{array}{l}\text { Being in managed care, no SES } \\
\text { association }\end{array}$ \\
\hline $\begin{array}{l}\text { Improved treatments of } \\
\text { currently under-treated } \\
\text { conditions. }\end{array}$ & $\begin{array}{l}\text { Respondent given medication } \\
\text { mentioned in advertisement and } \\
\text { doctor said it would benefit } \\
\text { patient. }\end{array}$ & $67(2.1 \%)[1.6-2.8 \%]$ & $\begin{array}{l}\text { Low education, low income, not } \\
\text { proactive about health } \\
\text { information }\end{array}$ \\
\hline Worsened treatment & $\begin{array}{l}\text { Respondents given medication } \\
\text { requested but doctor said it } \\
\text { would not benefit patient }\end{array}$ & $26(0.8 \%)[0.5-1.2]$ & Age $18-24$ \\
\hline \multicolumn{4}{|l|}{ Psychosocial benefits } \\
\hline \multirow{2}{*}{$\begin{array}{l}\text { Increased sense of confidence } \\
\text { and control by patient during } \\
\text { physician visit. }\end{array}$} & $\begin{array}{l}\text { Respondent felt more confident } \\
\text { during visit as a result of DTCA }\end{array}$ & $142(4.4 \%)[3.7-5.4 \%]$ & No SES association \\
\hline & $\begin{array}{l}\text { Respondent felt more in control } \\
\text { during visit as a result of DTCA }\end{array}$ & $168(5.2 \%)[4.4-6.2 \%]$ & $\begin{array}{l}\text { Women, not proactive about } \\
\text { health information }\end{array}$ \\
\hline \multicolumn{4}{|l|}{$\begin{array}{l}\text { Effect on doctor-patient } \\
\text { relationship }\end{array}$} \\
\hline $\begin{array}{l}\text { Enhanced disclosure of health } \\
\text { concerns to doctor }\end{array}$ & $\begin{array}{l}\text { Respondent disclosed health } \\
\text { concerns to physician as a result } \\
\text { of DTCA }\end{array}$ & $455(14.2 \%)[12.8-15.8 \%]$ & $\begin{array}{l}\text { Low income, nonwhite, chronic } \\
\text { disease, proactive about health } \\
\text { information }\end{array}$ \\
\hline \multirow[t]{4}{*}{$\begin{array}{l}\text { Changed global rating of } \\
\text { relationship }\end{array}$} & $\begin{array}{l}\text { Respondent's assessment of effect } \\
\text { of discussing information from } \\
\text { DTCA on doctor-patient } \\
\text { relationship }\end{array}$ & & \\
\hline & Improved & $51(1.6 \%)[1.2-2.2 \%]$ & $\begin{array}{l}\text { Change in relationship associated } \\
\text { with SES. }\end{array}$ \\
\hline & Neutral & $163(5.1)[4.3-6.0 \%]$ & \\
\hline & Worsened & $11(0.3)[0.1-1.0 \%]$ & $\begin{array}{l}\text { Worsened relationship associated } \\
\text { with the request's not being } \\
\text { filled. }\end{array}$ \\
\hline $\begin{array}{l}\text { Failure by patient to } \\
\text { acknowledge doctor's } \\
\text { expertise or doctor } \\
\text { experiencing difficulty with } \\
\text { knowledgeable/activated } \\
\text { patient }\end{array}$ & Doctor acted challenged & $30(0.9 \%)[0.6-1.4 \%]$ & Low education \\
\hline Serious dissatisfaction by patient & $\begin{array}{l}\text { Respondent sought } 2 \text { nd opinion, } \\
\text { changed doctor or health plan) }\end{array}$ & $46(1.4 \%)[1.0-2.2 \%]$ & $\begin{array}{l}\text { Low SES, no relationship with } \\
\text { having request filled. }\end{array}$ \\
\hline \multicolumn{4}{|l|}{ Effects on health care system } \\
\hline $\begin{array}{l}\text { Increased costs, without } \\
\text { commensurate health gains. }\end{array}$ & $\begin{array}{l}\text { Number of respondents who } \\
\text { scheduled visit to physician to } \\
\text { discuss ad } \\
\text { Number of respondents who made } \\
\text { specific requests } \\
\text { Number of respondents who } \\
\text { received what they asked for }\end{array}$ & $161(5.0 \%)[4.2-5.9 \%]$ & $\begin{array}{l}\text { Low education, being in managed } \\
\text { care }\end{array}$ \\
\hline
\end{tabular}

* See previous article ${ }^{15}$ for full description of hypotheses.

† Outcomes are presented as a percentage of the total population of respondents to allow a comparison of the various effects on a population.

SES, socioeconomic status. 
knowledgeable patient or that the patient was failing to acknowledge the doctor's professional expertise. Independent variables were categorized to maximize opportunities to determine the effect of low SES.

Univariate relationships between independent variables and the dependent variables were calculated using the $\chi^{2}$ statistic or Fisher exact test as appropriate. Multivariate relationships were analyzed using the same methods of stepwise multiple logistic regression and adjustment for weighting described in the previous article. ${ }^{15}$

\section{Results}

\section{Characteristics of Respondents ( $n=3209)$}

The characteristics of the respondents before and after weighting are presented in Table 2, which allows for an assessment of the demographic representativeness of our sample. The small differences between unweighted and weighted data suggest that the random-digit dialing method succeeded in generating a sample similar in profile to that of the US population.

Among the 308 respondents who had discussed information from DTCA with their physician, 82 were not asked about this because they had already responded to questions about taking information from the Internet to a visit (Figure 1). The 226 who did provide information were more likely to be unemployed ( $33 \%$ vs $20 \%, P=.036$ ); less likely to be in good health $(24 \%$ vs $43 \%, P=.011)$; and more likely to have a regular doctor $(95 \%$ vs $82 \%$, $P=.008)$ than the 82 who did not provide information.

\section{Overall Perceptions of DTCA}

Most respondents were fairly positive about the recent increase in drug advertisements; 7\% [95\% confidence interval (CI) 6 to $8 \%$ ] thought it was a very good thing and $40 \%$ (95\% CI, 38 to $43 \%$ ) thought it was a good thing. Thirty-four percent (95\% CI, 31 to $36 \%$ ) were neutral, and only $19 \%$ (95\% CI, 18 to $21 \%$ ) thought it was either very bad or bad. There was no association between socioeconomic status and overall opinion about DTCA. Table 3 presents the proportions of respondents who had seen a DTCA in the preceding 12 months who agreed with various statements about potential benefits and harms of DTCA.

\section{Response to DTCA}

Eighty-three percent (95\% CI, 81 to $85 \%$ ) of all respondents had seen an advertisement for a prescription medication in the preceding 12 months. The most common source of DTCA was television (94\%), followed by newspapers or journals (62\%) and the radio (22\%). In the preceding 12 months, $20 \%$ (95\% CI, 19 to $22 \%$; $\mathrm{n}=649$ ) of respondents had seen a drug advertisement relevant to their health, and $10 \%$ (95\% CI, 8 to $11 \%$; $=308$ ) had discussed information in a drug advertisement with their doctors (Figure 1). Seventy-seven percent $(n=171)$ of these conversations were with a primary care physician.

\section{Effects of DTCA}

Table 1 summarizes our research questions, outcome variables, the number of respondents who stated they had experienced each outcome, and the significant associations with each outcome. Both in Table 1 and the text, the main outcomes are grouped into clinical benefits and harms, psychosocial benefits, effect on the doctor-patient relationship, and effect on health service utilization.

\section{Clinical Benefits and Harms of DTCA}

Requested Preventive Care

Of the 3209 respondents, 203 had requested preventive care, such as a screening or blood test. Socioeconomic status was strongly associated with this outcome; people who had not completed high school, Hispanics, and people with chronic disease were all more likely to seek preventive care as a result of information in a drug advertisement (Table 4).

\section{Scheduled Checkup}

Of the 3209 respondents, 189 had visited a health professional for a check-up as a result of information in a DTCA. The relationship between this outcome and socioeconomic status was very similar to that for requesting preventive care (data not shown).

\section{Diagnosed with Condition Mentioned in Advertisement}

Of the 226 people who discussed information from a drug advertisement with a doctor, 28 were told they either had, or were at risk for, the condition mentioned in the advertisement during or immediately after the visit during which DTCA was discussed. This outcome was not associated with 


\begin{tabular}{|c|c|c|c|c|}
\hline \multirow[b]{2}{*}{ Characteristic } & \multicolumn{2}{|c|}{ Unweighted } & \multicolumn{2}{|c|}{ Weighted* } \\
\hline & $\%$ & $\mathrm{n}$ & $\%$ & $\mathrm{n}$ \\
\hline \multicolumn{5}{|l|}{ Demographics } \\
\hline $\begin{array}{l}\text { Age } \\
\begin{array}{l}18-24 \\
25-34 \\
35-44 \\
45-54 \\
55-64 \\
65+\end{array}\end{array}$ & $\begin{array}{r}9 \\
18 \\
23 \\
20 \\
12 \\
18\end{array}$ & $\begin{array}{l}275 \\
567 \\
726 \\
642 \\
384 \\
575\end{array}$ & $\begin{array}{l}15.5 \\
18.5 \\
22 \\
18 \\
11 \\
15\end{array}$ & $\begin{array}{l}489 \\
583 \\
700 \\
573 \\
353 \\
462\end{array}$ \\
\hline $\begin{array}{l}\text { Gender } \\
\text { Female } \\
\text { Male }\end{array}$ & $\begin{array}{l}55 \\
45\end{array}$ & $\begin{array}{l}1757 \\
1452\end{array}$ & $\begin{array}{l}48 \\
53\end{array}$ & $\begin{array}{l}1523 \\
1686\end{array}$ \\
\hline $\begin{array}{l}\text { Race } \\
\text { White (non-Hispanic) } \\
\text { Black/African American (non-Hispanic) } \\
\text { Hispanic } \\
\text { Asian/Pacific Islanders (non-Hispanic) } \\
\text { Other (non-Hispanic) }\end{array}$ & $\begin{array}{r}78 \\
10 \\
8 \\
2 \\
3\end{array}$ & $\begin{array}{r}2477 \\
319 \\
249 \\
58 \\
82\end{array}$ & $\begin{array}{r}71 \\
12 \\
11 \\
4 \\
3\end{array}$ & $\begin{array}{r}2247 \\
390 \\
342 \\
116 \\
90\end{array}$ \\
\hline $\begin{array}{l}\text { Educational status } \\
\text { Less than high school } \\
\text { Completed high school } \\
\text { Completed college } \\
\text { Advanced degree }\end{array}$ & $\begin{array}{r}4 \\
59 \\
27 \\
11\end{array}$ & $\begin{array}{r}114 \\
1870 \\
858 \\
354\end{array}$ & $\begin{array}{r}5 \\
71 \\
17 \\
7\end{array}$ & $\begin{array}{r}161 \\
2274 \\
548 \\
211\end{array}$ \\
\hline $\begin{array}{l}\text { Annual income } \\
<\$ 35,000 \\
\$ 35,000-\$ 74,999 \\
\$ 75,000-\$ 124,999 \\
>\$ 125,000\end{array}$ & $\begin{array}{r}47 \\
34 \\
13 \\
6\end{array}$ & $\begin{array}{r}1306 \\
962 \\
366 \\
176\end{array}$ & $\begin{array}{r}53 \\
32 \\
11 \\
4\end{array}$ & $\begin{array}{r}1481 \\
904 \\
309 \\
120\end{array}$ \\
\hline $\begin{array}{l}\text { Health status } \\
\text { Good } \\
\text { Poor } †\end{array}$ & $\begin{array}{l}62 \\
38\end{array}$ & $\begin{array}{l}1977 \\
1224\end{array}$ & $\begin{array}{l}73 \\
27\end{array}$ & $\begin{array}{r}2333 \\
871\end{array}$ \\
\hline $\begin{array}{l}\text { Health care factors } \\
\text { Health insurance status } \\
\text { Insured } \\
\text { Not insured }\end{array}$ & $\begin{array}{r}93 \\
7\end{array}$ & $\begin{array}{r}2957 \\
236\end{array}$ & $\begin{array}{l}85 \\
15\end{array}$ & $\begin{array}{r}2698 \\
474\end{array}$ \\
\hline $\begin{array}{l}\text { In managed care? } \\
\text { Yes } \\
\text { No }\end{array}$ & $\begin{array}{l}65 \\
35\end{array}$ & $\begin{array}{l}1889 \\
1008\end{array}$ & $\begin{array}{l}66 \\
34\end{array}$ & $\begin{array}{r}1743 \\
886\end{array}$ \\
\hline$\%$ of Respondents who responded 'often' or 'sometimes' to the following state & & & & \\
\hline $\begin{array}{l}\text { Doctors have excellent medical skills } \\
\text { Doctors are open to what patients say } \\
\text { Doctors are behind in their knowledge of research and the latest treatments. } \\
\text { Doctors spend enough time with their patients } \\
\text { Proactive approach to health information } \neq \\
\text { Yes } \\
\text { No }\end{array}$ & $\begin{array}{l}95 \\
83 \\
74 \\
69 \\
40 \\
60\end{array}$ & $\begin{array}{l}2999 \\
2633 \\
2261 \\
2161 \\
1268 \\
1932\end{array}$ & $\begin{array}{l}95 \\
84 \\
74 \\
69 \\
35 \\
65\end{array}$ & $\begin{array}{l}2989 \\
2648 \\
2259 \\
2191 \\
\\
1134 \\
2068\end{array}$ \\
\hline $\begin{array}{l}\text { Have a regular doctor? } \\
\text { Yes } \\
\text { No }\end{array}$ & $\begin{array}{l}85 \\
15\end{array}$ & $\begin{array}{r}2728 \\
477\end{array}$ & $\begin{array}{l}81 \\
19\end{array}$ & $\begin{array}{r}2596 \\
612\end{array}$ \\
\hline $\begin{array}{l}\text { Rating of level of care from regular doctor, or doctor seen most often? } \\
\text { Excellent/very good } \\
\text { Good } \\
\text { Fair/poor }\end{array}$ & $\begin{array}{r}71 \\
21 \\
8\end{array}$ & $\begin{array}{r}2058 \\
620 \\
225\end{array}$ & $\begin{array}{r}69 \\
22 \\
9\end{array}$ & $\begin{array}{r}1948 \\
612 \\
246\end{array}$ \\
\hline $\begin{array}{l}\text { How often does regular doctor encourage you to look for information? } \\
\text { Often/sometimes } \\
\text { Hardly ever/never }\end{array}$ & $\begin{array}{l}38 \\
62\end{array}$ & $\begin{array}{l}1033 \\
1667\end{array}$ & $\begin{array}{l}38 \\
62\end{array}$ & $\begin{array}{r}971 \\
1599\end{array}$ \\
\hline
\end{tabular}

* Data were weighted to adjust for unequal probability of selection (including the oversample of persons in poor health). To adjust for survey nonresponse, stratification weights were developed using the March 2000 Current Population Survey from the US Census Bureau as standard. The poststratification weights were based on gender within age within race, as well as education, health insurance status (insured vs. uninsured), and household size. This weighting procedure results in a sample that is representative of the US population.

† Poor health was defined as having a chronic disease or disability that prevented respondent from participating fully in school, work, housework, or other activities; having been hospitalized other than for a normal delivery within the past $12 \mathrm{months;}$ and/or the respondent defining their health as fair or poor rather than excellent, very good, or good.

$\ddagger$ See text for definition. 


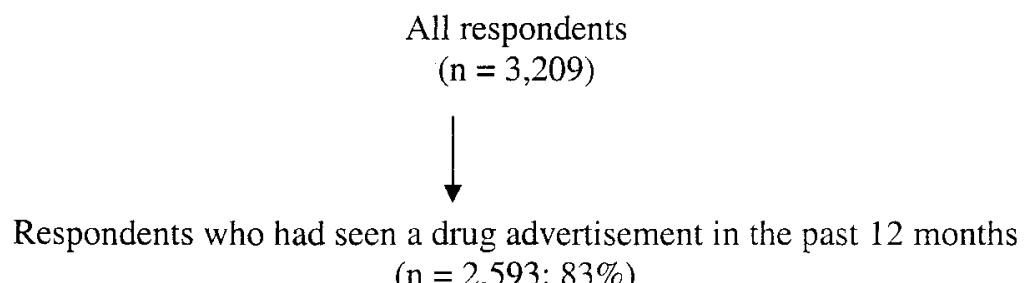

$(\mathrm{n}=2,593 ; 83 \%)$

Respondents who had seen a drug advertisement that was personally relevant in the past 12 months

$(\mathrm{n}=649 ; 20 \%)$

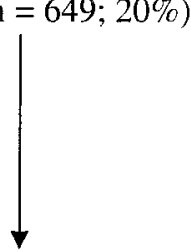

Respondents who had talked about information in a drug advertisement during a visit to their physician

$(\mathrm{n}=308 ; 10 \%)$

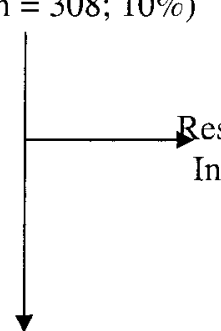

Respondents who answered questions about the last visit where they had talked about information in a drug advertisement

$$
(n=226)
$$

Figure 1. Flow chart of respondents.

socioeconomic status but was associated with being in managed care $(2 \%$ in managed care vs $0 \%$ not in managed care; $P=.012$ ). A further 149 respondents had previously been diagnosed with the condition mentioned in the advertisement.

\section{Improved Treatment}

Of 226 respondents, 67 were given the medication mentioned in the drug advertisement and told by their doctors that it would improve their health. This outcome was more prevalent in people with low incomes (61\% annual income $<\$ 15,000$ vs $35 \% \geq \$ 15,000, P=.032)$; low educational status (61\% not completed high school vs $34 \%$ for high school graduate or higher, $P=.021$ ); and people who were not proactive about health information ( $45 \%$ not proactive vs $25 \%$ proactive, $P=.006$ ).
Table 3. Respondents' Views about Effects of DTCA $(\mathrm{n}=\mathbf{2 5 9 3})$

Advertisements for prescription drugs: \% Agreeing

Give patients confidence to talk to their doctors about their concerns

Encourage people to follow treatment instructions or advice from their doctors

Drive up the cost of prescription drugs

Improve people's understanding of medical conditions and treatments

Help patients get treatments they wouldn't otherwise get

Promote unnecessary fear of the side effects $\quad 54$

Promote unnecessary visits to doctors $\quad 48$

Cause patients to take up more of their 38 doctors' time

Interfere with good relationships between doctors and patients 


\begin{tabular}{|c|c|c|c|}
\hline & $\mathrm{n}$ & \% Yes (Mostly or Partly) & $P$ \\
\hline Total & 2590 & 8 (95\% CI 7-9\%) & \\
\hline \multicolumn{4}{|l|}{ Socioeconomic variables } \\
\hline $\begin{array}{l}\text { Annual Income } \\
\text { Less than } \$ 15,000 \\
\$ 15,000-\$ 24,999 \\
\$ 25,000-\$ 49,999 \\
\$ 50,000 \text { or more }\end{array}$ & $\begin{array}{l}357 \\
401 \\
808 \\
759\end{array}$ & $\begin{array}{r}9 \\
10 \\
7 \\
7\end{array}$ & 0.150 \\
\hline $\begin{array}{l}\text { Education } \\
\text { Less than high school } \\
\text { Completed high school } \\
\text { Some college, no graduation } \\
\text { College graduate or higher degree }\end{array}$ & $\begin{array}{l}242 \\
890 \\
757 \\
691\end{array}$ & $\begin{array}{r}16 \\
8 \\
7 \\
7\end{array}$ & $<0.001$ \\
\hline $\begin{array}{l}\text { Race/Ethnicity } \\
\text { White, non-Hispanic } \\
\text { Black/African American, non-Hispanic } \\
\text { Hispanic } \\
\text { Asian, Pacific Islander, non-Hispanic }\end{array}$ & $\begin{array}{r}1947 \\
287 \\
186 \\
83\end{array}$ & $\begin{array}{r}7 \\
8 \\
15 \\
7\end{array}$ & 0.005 \\
\hline $\begin{array}{l}\text { Employment status } \\
\text { Not employed } \\
\text { Employed part-time } \\
\text { Employed full-time } \\
\text { Self-employed } \\
\text { Other }\end{array}$ & $\begin{array}{r}183 \\
258 \\
1276 \\
202 \\
661\end{array}$ & $\begin{array}{r}10 \\
8 \\
8 \\
7 \\
7\end{array}$ & 0.695 \\
\hline $\begin{array}{l}\text { Health Status } \\
\text { Poor health } \\
\text { Good health } \\
\text { Chronic disease }\end{array}$ & $\begin{array}{r}181 \\
1156 \\
1252\end{array}$ & $\begin{array}{r}5 \\
5 \\
11\end{array}$ & $<0.001$ \\
\hline $\begin{array}{l}\text { Insurance status } \\
\text { Insured through work or privately } \\
\text { Medicare } \\
\text { Medicaid } \\
\text { Not insured }\end{array}$ & $\begin{array}{r}2049 \\
117 \\
63 \\
331\end{array}$ & $\begin{array}{r}8 \\
9 \\
10 \\
6\end{array}$ & 0.489 \\
\hline $\begin{array}{l}\text { Managed care? } \\
\text { Yes } \\
\text { No }\end{array}$ & $\begin{array}{r}1479 \\
708\end{array}$ & $\begin{array}{l}9 \\
7\end{array}$ & 0.221 \\
\hline $\begin{array}{l}\text { Gender } \\
\text { Male } \\
\text { Female }\end{array}$ & $\begin{array}{l}1210 \\
1381\end{array}$ & $\begin{array}{l}8 \\
8\end{array}$ & 0.747 \\
\hline $\begin{array}{l}\text { Age } \\
18-24 \\
25-44 \\
45-64 \\
65+\end{array}$ & $\begin{array}{r}383 \\
1052 \\
775 \\
352\end{array}$ & $\begin{array}{r}7 \\
7 \\
12 \\
6\end{array}$ & $<0.001$ \\
\hline \multicolumn{4}{|l|}{ Attitudes to health information } \\
\hline $\begin{array}{l}\text { Proactive about health information? } \\
\text { Yes } \\
\text { No }\end{array}$ & $\begin{array}{r}972 \\
1615\end{array}$ & $\begin{array}{r}10 \\
6\end{array}$ & $<0.001$ \\
\hline \multicolumn{4}{|l|}{ Relationship with health care professionals } \\
\hline $\begin{array}{l}\text { Do you have a regular doctor or health care professional? } \\
\text { Yes } \\
\text { No }\end{array}$ & $\begin{array}{r}2139 \\
450\end{array}$ & $\begin{array}{l}8 \\
8\end{array}$ & 0.715 \\
\hline $\begin{array}{l}\text { How do you rate the overall level of health care provided by your regular doctor? } \\
\text { Excellent/very good/good } \\
\text { Fair/poor }\end{array}$ & $\begin{array}{r}2127 \\
187\end{array}$ & $\begin{array}{r}7 \\
14\end{array}$ & $<0.001$ \\
\hline
\end{tabular}

\section{Worsened Treatment}

Twenty-six people reported requesting and receiving an advertised medication that their doctor said would not help them. This was more likely to occur for persons aged 18 to 24 than for those over 25 (75\% vs $9 \%, P<.001)$.

\section{Psychosocial Benefits of DTCA}

Enhanced Sense of Control during Visit

Of 226 people, 168 said that they had felt more in control during a visit to a doctor as a result of information in a DTCA. Women were more likely than men to experience this enhanced sense of 
control ( $85 \%$ vs $68 \%, P=.003$ ), as were people who were not proactive about health information compared with those who were $(83 \%$ vs $72 \%, P=$ $.041)$.

\section{Enhanced Sense of Confidence during Visit}

Of 226 people, 142 said they had felt more confident during the visit as a result of information in a drug advertisement. This was not related to respondents' socioeconomic status.

\section{Effects of DTCA on Doctor-Patient Relationship Disclosed Health Concerns to Doctor}

Of 3209 people, 455 stated they had talked about concerns about their own health to a doctor as a result of information in a DTCA. This outcome was associated with low socioeconomic status (Table 5).

\section{Changed Global Rating of Doctor-Patient Relationship}

Of the 226 people who provided information about discussing DTCA during a visit, 51 thought the relationship had improved as a result, 163 thought there had been no change, and 11 thought it had worsened. This outcome was strongly related to socioeconomic status. Respondents who made a request but did not get what they asked for were more likely to report a worsened doctor-patient relationship (Table 6).

\section{Doctor Acted Challenged}

Of the 226 people, 30 reported that their doctors had acted as if they felt their authority was being challenged by the patient's discussing information from a drug advertisement during a visit. Respondents were more likely to perceive their doctor as acting challenged if they were of low educational status (33\% not completed high school vs $12 \%$ graduated from high school, $P=.010)$ and if they were proactive about health information (18\% proactive vs $9 \%$ not proactive, $P=.046$ ).

\section{Patient Manifested Serious Dissatisfaction after Discussing DTCA during a Visit}

Of 226 people, 46 sought a second opinion $(\mathrm{n}=$ $29)$, changed their doctor $(n=19)$, or changed their health care plans $(n=11)$ as a result of dissatisfaction with a discussion with their doctor about DTCA during a visit. This was more prevalent in people of low socioeconomic status but was not related to getting or not getting a specific intervention requested (Table 7).

\section{Effects of DTCA on Health Care System}

Scheduled a Visit to a Physician to Discuss Information in DTCA

Most respondents waited to discuss information until they had some other reason for visiting their doctors; however, 55 of 226 respondents scheduled a visit to a physician specifically $(n=27)$ or partly $(\mathrm{n}=28)$ to discuss information from an advertisement. This outcome was related to socioeconomic status, with people of low education (58\% not completed high school vs $22 \%$ completed high school, $P=.009)$ and people in managed care $(27 \%$ in managed care vs $13 \%$ not in managed care, $P=$ .021) more likely to do so.

\section{Requests Made and Filled}

One hundred and sixty-one people requested at least one intervention from their doctors as a result of DTCA. Most requests were for changes in medication $(\mathrm{n}=131)$, followed by tests $(\mathrm{n}=69)$ and referrals to a specialist $(n=50)$. Of these people, 89 received the specific intervention requested. Receiving the specific intervention requested was associated with higher socioeconomic status. Respondents were more likely to get what they asked for if they were white (whites $63 \%$ vs nonwhites $30 \%$, $P=.001)$ or had completed high school $(58 \%$ completed high school vs $29 \%$ not completed, $P=$ .033). There was no association with being in managed care and having requests filled.

\section{Discussion \\ Implications}

We found significant positive and negative effects of DTCA on health behaviors, health service utilization, and the doctor-patient relationship. The impact was greatest on people of low socioeconomic status. This information is important to those seeking to maximize the benefits and minimize the harms of DTCA.

DTCA encourages members of the public, particularly those of low socioeconomic status, who are traditionally considered hard to reach with public health campaigns, ${ }^{11,12}$ to request preventive care and schedule a checkup. It encourages people to disclose health concerns to their doctor, and en- 


\begin{tabular}{|c|c|c|c|}
\hline & $\mathrm{n}$ & $\begin{array}{c}\text { \% Yes } \\
\text { (Mostly or partly) }\end{array}$ & $P$ \\
\hline Total & 2589 & $18(95 \%$ CI $16-19 \%)$ & \\
\hline \multicolumn{4}{|l|}{ Socioeconomic variables } \\
\hline $\begin{array}{l}\text { Annual Income } \\
\text { Less than } \$ 15,000 \\
\$ 15,000-\$ 24,999 \\
\$ 25,000-\$ 49,999 \\
\$ 50,000 \text { or more }\end{array}$ & $\begin{array}{l}356 \\
402 \\
809 \\
759\end{array}$ & $\begin{array}{l}20 \\
25 \\
18 \\
14\end{array}$ & $<0.001$ \\
\hline $\begin{array}{l}\text { Education } \\
\text { Less than high school } \\
\text { Completed high school } \\
\text { Some college, no graduation } \\
\text { College graduate or higher degree }\end{array}$ & $\begin{array}{l}240 \\
891 \\
757 \\
690\end{array}$ & $\begin{array}{l}22 \\
20 \\
16 \\
15\end{array}$ & 0.022 \\
\hline $\begin{array}{l}\text { Race/Ethnicity } \\
\text { White, non-Hispanic } \\
\text { Black/African-American, non-Hispanic } \\
\text { Hispanic } \\
\text { Asian, Pacific Islander, non-Hispanic }\end{array}$ & $\begin{array}{r}1945 \\
288 \\
186 \\
83\end{array}$ & $\begin{array}{l}17 \\
24 \\
21 \\
21\end{array}$ & 0.007 \\
\hline $\begin{array}{l}\text { Employment status } \\
\text { Not employed } \\
\text { Employed part-time } \\
\text { Employed full-time } \\
\text { Self-employed } \\
\text { Other }\end{array}$ & $\begin{array}{r}181 \\
259 \\
1279 \\
201 \\
658\end{array}$ & $\begin{array}{l}12 \\
22 \\
17 \\
16 \\
19\end{array}$ & 0.066 \\
\hline $\begin{array}{l}\text { Health Status } \\
\text { Poor health } \\
\text { Good health } \\
\text { Chronic disease }\end{array}$ & $\begin{array}{r}182 \\
1157 \\
1250\end{array}$ & $\begin{array}{l}14 \\
13 \\
22\end{array}$ & $<0.001$ \\
\hline $\begin{array}{l}\text { Insurance status } \\
\text { Insured through work or privately } \\
\text { Medicare } \\
\text { Medicaid } \\
\text { Not insured }\end{array}$ & $\begin{array}{r}2050 \\
115 \\
64 \\
332\end{array}$ & $\begin{array}{l}17 \\
24 \\
16 \\
16\end{array}$ & 0.281 \\
\hline $\begin{array}{l}\text { Managed care } \\
\text { Yes } \\
\text { No }\end{array}$ & $\begin{array}{r}1479 \\
706\end{array}$ & $\begin{array}{l}18 \\
16\end{array}$ & 0.226 \\
\hline $\begin{array}{l}\text { Gender } \\
\text { Male } \\
\text { Female }\end{array}$ & $\begin{array}{l}1210 \\
1379\end{array}$ & $\begin{array}{l}18 \\
17\end{array}$ & 0.415 \\
\hline $\begin{array}{l}\text { Age } \\
18-24 \\
25-44 \\
45-64 \\
65+\end{array}$ & $\begin{array}{r}383 \\
1053 \\
775 \\
349\end{array}$ & $\begin{array}{l}19 \\
15 \\
20 \\
18\end{array}$ & 0.046 \\
\hline \multicolumn{4}{|l|}{ Attitudes to health information } \\
\hline $\begin{array}{l}\text { Proactive about health information? } \\
\text { Yes } \\
\text { No }\end{array}$ & $\begin{array}{r}970 \\
1615\end{array}$ & $\begin{array}{l}22 \\
15\end{array}$ & $<0.001$ \\
\hline \multicolumn{4}{|l|}{ Relationship with health care professionals } \\
\hline $\begin{array}{l}\text { Do you have a regular doctor or health care professional? } \\
\text { Yes } \\
\text { No }\end{array}$ & $\begin{array}{r}2137 \\
450\end{array}$ & $\begin{array}{l}18 \\
16\end{array}$ & 0.483 \\
\hline $\begin{array}{l}\text { How do you rate the overall level of health care provided by your regular doctor? } \\
\text { Excellent/very good/good } \\
\text { Fair/poor }\end{array}$ & $\begin{array}{r}2125 \\
187\end{array}$ & $\begin{array}{l}18 \\
27\end{array}$ & 0.003 \\
\hline
\end{tabular}

hances some patients' sense of confidence and control during a visit. From a policy or population health perspective, these undoubted benefits have to be weighed against the well-documented effect of DTCA on increasing health costs. In our previ- ous article, we demonstrated that physicians experience DTCA as having an adverse effect on time efficiency and resulting in numerous, clinically inappropriate requests for tests, specialist referrals, and changes in medication. About half such re- 


\begin{tabular}{|c|c|c|c|c|c|}
\hline & $\mathrm{n}$ & $\%$ Improved & $\%$ Neutral & $\%$ Worsened & $P$ \\
\hline Total $(95 \% \mathrm{CI})$ & 225 & $23(17 \%$ to $29 \%)$ & $73(65-79 \%)$ & $5(2-13 \%)$ & \\
\hline \multicolumn{6}{|l|}{ Socioeconomic variables } \\
\hline $\begin{array}{l}\text { Annual Income } \\
\text { Less than } \$ 15,000 \\
\$ 15,000-\$ 24,999 \\
\$ 25,000-\$ 49,999 \\
\$ 50,000 \text { or more }\end{array}$ & $\begin{array}{l}23 \\
42 \\
63 \\
73\end{array}$ & $\begin{array}{l}22 \\
14 \\
22 \\
21\end{array}$ & $\begin{array}{l}44 \\
86 \\
75 \\
78\end{array}$ & $\begin{array}{r}35 \\
0 \\
3 \\
1\end{array}$ & $<0.001$ \\
\hline $\begin{array}{l}\text { Education } \\
\text { Less than high school } \\
\text { Completed high school } \\
\text { Some college, no graduation } \\
\text { College graduate or higher degree }\end{array}$ & $\begin{array}{l}19 \\
73 \\
60 \\
71\end{array}$ & $\begin{array}{l}26 \\
29 \\
15 \\
21\end{array}$ & $\begin{array}{l}42 \\
69 \\
83 \\
78\end{array}$ & $\begin{array}{r}32 \\
3 \\
2 \\
1\end{array}$ & $<0.001$ \\
\hline $\begin{array}{l}\text { Race/Ethnicity } \\
\text { White, non-Hispanic } \\
\text { Black, non-Hispanic } \\
\text { Hispanic } \\
\text { Asian, non-Hispanic }\end{array}$ & $\begin{array}{r}169 \\
33 \\
11 \\
2\end{array}$ & $\begin{array}{r}22 \\
21 \\
27 \\
100\end{array}$ & $\begin{array}{r}77 \\
61 \\
73 \\
0\end{array}$ & $\begin{array}{r}2 \\
18 \\
0 \\
0\end{array}$ & $<0.001$ \\
\hline $\begin{array}{l}\text { Employment status } \\
\text { Not employed } \\
\text { Employed part-time } \\
\text { Employed full-time } \\
\text { Self-employed } \\
\text { Other }\end{array}$ & $\begin{array}{r}15 \\
30 \\
101 \\
16 \\
58\end{array}$ & $\begin{array}{l}33 \\
10 \\
26 \\
13 \\
24\end{array}$ & $\begin{array}{l}27 \\
87 \\
73 \\
82 \\
74\end{array}$ & $\begin{array}{r}40 \\
3 \\
1 \\
6 \\
2\end{array}$ & $<0.001$ \\
\hline $\begin{array}{l}\text { Health Status } \\
\text { Poor health } \\
\text { Good health } \\
\text { Chronic disease }\end{array}$ & $\begin{array}{r}16 \\
55 \\
154\end{array}$ & $\begin{array}{l}25 \\
24 \\
22\end{array}$ & $\begin{array}{l}75 \\
76 \\
71\end{array}$ & $\begin{array}{l}0 \\
0 \\
7\end{array}$ & 0.254 \\
\hline $\begin{array}{l}\text { Insurance status } \\
\text { Insured through work or privately } \\
\text { Medicare } \\
\text { Medicaid } \\
\text { Not insured }\end{array}$ & $\begin{array}{r}154 \\
33 \\
24 \\
13\end{array}$ & $\begin{array}{l}21 \\
27 \\
25 \\
15\end{array}$ & $\begin{array}{l}76 \\
67 \\
75 \\
46\end{array}$ & $\begin{array}{r}3 \\
6 \\
0 \\
39\end{array}$ & $<0.001$ \\
\hline $\begin{array}{l}\text { Managed care? } \\
\text { Yes } \\
\text { No }\end{array}$ & $\begin{array}{r}143 \\
65\end{array}$ & $\begin{array}{l}23 \\
25\end{array}$ & $\begin{array}{l}73 \\
74\end{array}$ & $\begin{array}{l}4 \\
2\end{array}$ & 0.726 \\
\hline $\begin{array}{l}\text { Gender } \\
\text { Male } \\
\text { Female }\end{array}$ & $\begin{array}{r}98 \\
127\end{array}$ & $\begin{array}{l}31 \\
16\end{array}$ & $\begin{array}{r}67 \\
7\end{array}$ & $\begin{array}{r}2 \\
77\end{array}$ & 0.011 \\
\hline $\begin{array}{l}\text { Age } \\
\begin{array}{l}18-24 \\
25-44 \\
45-64 \\
65+\end{array}\end{array}$ & $\begin{array}{l}16 \\
82 \\
86 \\
39\end{array}$ & $\begin{array}{l}31 \\
11 \\
34 \\
18\end{array}$ & $\begin{array}{l}63 \\
81 \\
64 \\
80\end{array}$ & $\begin{array}{l}6 \\
9 \\
2 \\
3\end{array}$ & 0.011 \\
\hline \multicolumn{6}{|l|}{ Attitudes to health information } \\
\hline $\begin{array}{l}\text { Proactive about health information? } \\
\text { Yes } \\
\text { No }\end{array}$ & $\begin{array}{l}104 \\
121\end{array}$ & $\begin{array}{l}19 \\
26\end{array}$ & $\begin{array}{l}80 \\
66\end{array}$ & $\begin{array}{l}1 \\
8\end{array}$ & 0.014 \\
\hline \multicolumn{6}{|l|}{ Relationship with health care professionals } \\
\hline $\begin{array}{l}\text { Do you have a regular doctor or health care professional? } \\
\text { Yes } \\
\text { No }\end{array}$ & $\begin{array}{r}212 \\
12\end{array}$ & $\begin{array}{r}23 \\
8\end{array}$ & $\begin{array}{l}72 \\
83\end{array}$ & $\begin{array}{l}5 \\
8\end{array}$ & 0.447 \\
\hline $\begin{array}{l}\text { How do you rate the overall level of health care } \\
\text { provided by your regular doctor? } \\
\text { Excellent/very good/good } \\
\text { Fair/poor }\end{array}$ & $\begin{array}{r}200 \\
23\end{array}$ & $\begin{array}{l}24 \\
17\end{array}$ & $\begin{array}{l}75 \\
52\end{array}$ & $\begin{array}{r}2 \\
30\end{array}$ & 0.001 \\
\hline $\begin{array}{l}\text { Did you get specific intervention requested? } \\
\text { Yes } \\
\text { No }\end{array}$ & $\begin{array}{l}89 \\
70\end{array}$ & $\begin{array}{l}27 \\
20\end{array}$ & $\begin{array}{l}73 \\
73\end{array}$ & $\begin{array}{l}0 \\
7\end{array}$ & 0.029 \\
\hline
\end{tabular}

quests are acquiesced to, with negative consequences on health care expenditure without commensurate health benefits. When considering the overall benefits and harms of DTCA, could the $\$ 2.5$ billion spent on DTCA last year have achieved equivalent health benefits if the techniques of ad- 
Table 7. Factors Associated with Manifestations of Serious Dissatisfaction (ie, Seeking Second Opinion, Changing Doctor, or Changing Health Plan)

\begin{tabular}{|c|c|c|c|}
\hline & $\mathrm{n}$ & $\%$ Yes & $P$ \\
\hline Total & 225 & $21(95 \%$ CI 14-29\%) & \\
\hline \multicolumn{4}{|l|}{ Socioeconomic variables } \\
\hline $\begin{array}{l}\text { Annual Income } \\
\text { Less than } \$ 15,000 \\
\$ 15,000-\$ 24,999 \\
\$ 25,000-\$ 49,999 \\
\$ 50,000 \text { or more }\end{array}$ & $\begin{array}{l}22 \\
43 \\
64 \\
73\end{array}$ & $\begin{array}{l}55 \\
30 \\
14 \\
11\end{array}$ & $<0.001$ \\
\hline $\begin{array}{l}\text { Education } \\
\text { Less than high school } \\
\text { Completed high school } \\
\text { Some college, no graduation } \\
\text { College graduate or higher degree }\end{array}$ & $\begin{array}{l}20 \\
75 \\
60 \\
71\end{array}$ & $\begin{array}{l}55 \\
23 \\
13 \\
14\end{array}$ & $<0.001$ \\
\hline $\begin{array}{l}\text { Race/Ethnicity } \\
\text { White, non-Hispanic } \\
\text { Black/African-American, non-Hispanic } \\
\text { Hispanic } \\
\text { Asian, Pacific Islander, non-Hispanic }\end{array}$ & $\begin{array}{r}170 \\
34 \\
12 \\
2\end{array}$ & $\begin{array}{r}19 \\
27 \\
17 \\
100\end{array}$ & 0.031 \\
\hline $\begin{array}{l}\text { Employment status } \\
\text { Not employed } \\
\text { Employed part-time } \\
\text { Employed full-time } \\
\text { Self-employed } \\
\text { Other }\end{array}$ & $\begin{array}{r}15 \\
30 \\
103 \\
17 \\
57\end{array}$ & $\begin{array}{r}53 \\
27 \\
8 \\
41 \\
26\end{array}$ & $<0.001$ \\
\hline $\begin{array}{l}\text { Health Status } \\
\text { Poor health } \\
\text { Good health } \\
\text { Chronic disease }\end{array}$ & $\begin{array}{r}16 \\
54 \\
155\end{array}$ & $\begin{array}{l}31 \\
15 \\
21\end{array}$ & 0.322 \\
\hline $\begin{array}{l}\text { Insurance status } \\
\text { Insured through work or privately } \\
\text { Medicare } \\
\text { Medicaid } \\
\text { Not insured }\end{array}$ & $\begin{array}{r}155 \\
34 \\
24 \\
13\end{array}$ & $\begin{array}{l}14 \\
18 \\
33 \\
85\end{array}$ & $<0.001$ \\
\hline $\begin{array}{l}\text { Managed care? } \\
\text { Yes } \\
\text { No }\end{array}$ & $\begin{array}{r}143 \\
65\end{array}$ & $\begin{array}{l}17 \\
15\end{array}$ & 0.800 \\
\hline $\begin{array}{l}\text { Gender } \\
\text { Male } \\
\text { Female }\end{array}$ & $\begin{array}{r}98 \\
128\end{array}$ & $\begin{array}{l}25 \\
18\end{array}$ & 0.231 \\
\hline $\begin{array}{l}\text { Age } \\
18-24 \\
25-44 \\
45-64 \\
65+\end{array}$ & $\begin{array}{l}16 \\
82 \\
86 \\
40\end{array}$ & $\begin{array}{l}69 \\
16 \\
13 \\
28\end{array}$ & $<0.001$ \\
\hline \multicolumn{4}{|l|}{ Attitudes to health information } \\
\hline $\begin{array}{l}\text { Proactive about health information? } \\
\text { Yes } \\
\text { No }\end{array}$ & $\begin{array}{l}103 \\
121\end{array}$ & $\begin{array}{l}24 \\
17\end{array}$ & 0.202 \\
\hline \multicolumn{4}{|l|}{ Relationship with health care professionals } \\
\hline $\begin{array}{l}\text { Do you have a regular doctor or health care professional? } \\
\text { Yes } \\
\text { No }\end{array}$ & $\begin{array}{r}213 \\
12\end{array}$ & $\begin{array}{l}20 \\
33\end{array}$ & 0.255 \\
\hline $\begin{array}{l}\text { How do you rate the overall level of health care provided } \\
\text { by your regular doctor? } \\
\text { Excellent/very good/good } \\
\text { Fair/poor }\end{array}$ & $\begin{array}{r}200 \\
23\end{array}$ & $\begin{array}{l}17 \\
52\end{array}$ & $<0.001$ \\
\hline $\begin{array}{l}\text { Did you get specific intervention requested? } \\
\text { Yes } \\
\text { No }\end{array}$ & $\begin{array}{l}89 \\
71\end{array}$ & $\begin{array}{l}18 \\
26\end{array}$ & 0.277 \\
\hline
\end{tabular}


vertising were focused on interventions that are known to improve health outcomes?

Although only $5 \%$ of respondents who brought DTCA information to their doctors reported a negative impact on the doctor-patient relationship, $13 \%$ perceived that their doctor felt his/her authority had been challenged, and $21 \%$ reported sufficient dissatisfaction that they sought a second opinion, a change in doctor, or a change in health care plan. These data could represent the positive outcome of an informed health consumer or the negative outcome of information provided by a biased third party that undermines the consumer's confidence in the health system. More research is needed to answer this question.

\section{Methodological Issues}

Several methodological issues limit the generalizability of our findings. First, this article reports on a secondary analysis of an extant data set, so not all hypotheses could be evaluated with the desired precision. In addition, lack of information from respondents' physicians and/or medical records precludes direct verification of respondents' perceptions. For example, we cannot determine whether requests made and filled were clinically indicated. Finally, respondents who discussed health information from the Internet with their physicians were not asked about the last time they took information from DTCA to a physician visit; hence, generalizability is restricted to the population that does not take information from the Internet to their doctor. However, these data are important because the 226 respondents who provided information about taking DTCA to a physician visit were of lower socioeconomic status than the 82 who did not. Other data from responses by all 3209 respondents indicate that DTCA has greatest effect on people of low socioeconomic status. To accommodate for this limitation, we conservatively assumed that the subsample that was not asked about discussing DTCA during a physician visit experienced no effects (ie, would not have sought an appointment or made a request). Thus, all our estimates of the population effects of DTCA are minimum estimates.

\section{Conclusions}

DTCA has positive and negative effects on health behaviors, health service utilization, and the doc- tor-patient relationship that are greatest on people of low socioeconomic status. The benefits of DTCA in terms of encouraging hard-to-reach sections of the population to attend for preventive care must be balanced against the increased costs to the health service from clinically inappropriate requests generated by DTCA.

We are grateful to the Robert Wood Johnson Foundation for funding this research, Kinga Zapert and Rachel Turner of Harris Interactive, Inc., for developing and fielding the survey instrument and to Joseph Catania, $\mathrm{PhD}$, director of the Health Survey Research Unit, for advice on the analytical strategy. Elizabeth Murray was a 2001-02 Harkness Fellow in Health Care Policy, supported by the Commonwealth Fund.

\section{References}

1. Rosenthal MB, Berndt ER, Donohue JM, Frank RG, Epstein AM. Promotion of prescription drugs to consumers. N Engl J Med 2002;346:498-505.

2. Lyles A. Direct marketing of pharmaceuticals to consumers. Annu Rev Public Health 2002;23:73-91.

3. Holmer AF. Direct-to-consumer advertisingstrengthening our health care system. N Engl J Med 2002;346:526-8.

4. Holmer AF. Direct-to-consumer prescription drug advertising builds bridges between patients and physicians. JAMA 1999;281:380-2.

5. Bonaccorso SN, Sturchio JL. For and Against: Direct to consumer advertising is medicalising normal human experience: Against. BMJ 2002;324:910-1.

6. Findlay SD. Direct-to-consumer promotion of prescription drugs. economic implications for patients, payers and providers. Pharmacoeconomics. 2001;19: $109-19$.

7. Mintzes B, Barer ML, Kravitz RL, et al. Influence of direct to consumer pharmaceutical advertising and patients' requests on prescribing decisions: 2 site cross sectional survey. BMJ 2002;324:278-9.

8. Hollon MF. Direct-to-consumer marketing of prescription drugs: creating consumer demand. JAMA 1999;281:382-4.

9. Spurgeon D. Doctors feel pressurised by direct to consumer advertising [editorial]. BMJ 1999;319: 1321.

10. Bell RA, Kravitz RL, Wilkes MS. Direct-to-consumer prescription drug advertising and the public. J Gen Intern Med 1999;14:651-7.

11. Understanding the effects of direct-to-consumer prescription drug advertising. Menlo Park (CA): Henry J. Kaiser Family Foundation; 2001. Available at: URL: http://www.kff.org/rxdrugs/loader.cfm? url=/commonspot/security/ getfile.cfm\&PageID $=13876$

12. Bell RA, Wilkes MS, Kravitz RL. Advertisementinduced prescription drug requests: patients' antici- 
pated reactions to a physician who refuses. J Fam Pract 1999;48:446-52.

13. Weissman JS, Blumenthal D, Silk AJ, Zapert K, Newman M, Leitman R. Consumers' reports on the health effects of direct-to-consumer drug advertising. Health Aff (Millwood) 2003;W3:82-95.

14. Bodenheimer T. Two advertisements for TV drug ads. Health Aff (Millwood) 2003;W3:112-5.
15. Murray E, Lo B, Pollack L, Donelan K, Lee K. Direct-to-consumer advertising: physicians' views of its effects on quality of care and the doctor-patient relationship. J Am Board Fam Pract 2003;16:513-24.

16. Murray E, Lo B, Pollack L, et al. The impact of health information on the internet on the physicianpatient relationship: patient perceptions. Arch Intern Med 2003;163:1727-34. 